\title{
ANTIOXIDANT AND CHEMOTHERAPEUTIC POTENTIAL OF CURCUMA AMADA RHIZOME EXTRACT ON BENZO(A)PYRENE INDUCED CERVICAL CARCINOMA IN SPRAGUE DAWLEY RATS
}

\author{
VASUNDRA DEVI PALANISAMY ${ }^{1 *}$, SUJA SAMIAPPAN ${ }^{2}$ \\ ${ }^{1}$ Department of Biochemistry, Dr. N.G.P Arts and Science College, Coimbatore, Tamil Nadu, India. ${ }^{2}$ Department of Biochemistry, Bharathiar \\ University, Coimbatore, Tamil Nadu, India. Email: vasundra.bio@gmail.com \\ Received: 09 November 2016, Revised and Accepted: 09 December 2016
}

ABSTRACT

Objective: To evaluate the antioxidant and chemotherapeutic potential of Curcuma amada Rhizome extract on benzo(a)pyrene (BaP) induced cervical carcinoma in Sprague Dawley rats.

\begin{abstract}
Methods: A total of 30 female Sprague Dawley rats were selected to establish cervical cancer model and then divided into 5 groups at random with six mice in each group. Group 1 control, Group 2 BaP (oral), Group 3 BaP for 8 weeks and post-treated with cisplatin (intravenous administration), Group $4 \mathrm{BaP}$ for 8 weeks and post-treated with $250 \mathrm{mg}$ of ethanol extract of $C$. amada (oral), Group $5 \mathrm{BaP}$ for 8 weeks and post-treated with $500 \mathrm{mg}$ of ethanol extract of $C$. amada (oral). 4 weeks after the treatment, the animals were sacrificed, serum separated, and cervical tissues were dissected. Antioxidants and the markers carcinoembryonic antigen (CEA), cancer antigens (CAs) 125, gamma glutamyltransferase (GTT) were assayed in serum and the tissue was used for analyzing tumor burden and sectioned for histopathological assays.10\% tissue homogenate was estimated for antioxidants and membrane-bound enzymes.
\end{abstract}

Results: BaP treated group showed significant $(\mathrm{p}<0.001)$ incidence of tumor burden, decreased activities of antioxidants, elevated lipid peroxidation, $\mathrm{Na}^{+} / \mathrm{K}^{+}$adenosine triphosphatase $\left(\mathrm{Na}^{+} \mathrm{K}^{+} \mathrm{ATPase}\right)$, Calcium adenosine triphosphatase $\left(\mathrm{Ca}^{2+} \mathrm{ATPase}\right)$, Magnesium adenosine triphosphatase ( $\left.\mathrm{Mg}^{2+} \mathrm{ATPase}\right)$, CEA, CA 125, GTT. Treatment with C. amada rhizome extract and standard drug cisplatin reverted the antioxidants, serum markers and tissue enzymes.

Conclusion: From the results, it can be concluded that $C$. amada Rhizome extract ameliorated BaP induced oxidative stress in the cervical carcinogenicity of rats.

Keywords: Curcuma amada, In vivo antioxidant, Chemotherapy, Benzo(a)pyrene, Cervical carcinoma, Tumor markers.

(C) 2017 The Authors. Published by Innovare Academic Sciences Pvt Ltd. This is an open access article under the CC BY license (http://creativecommons. org/licenses/by/4. 0/) DOI: http://dx.doi.org/10.22159/ajpcr.2017.v10i3.16106

\section{INTRODUCTION}

Cervical cancer is the rapid, uncontrolled growth of severely abnormal cells in the cervix. Although infection with human papillomavirus is the major known risk factor for the development of cervical cancer, other etiologic factors associated with this disease include cigarette smoking, deficiencies in micronutrients, lower socioeconomic status, and use of oral contraceptives. Epidemiological studies indicated that cigarette smoking is one of the cofactors that double the risk of cervical cancer [1] since it possesses polyaromatic hydrocarbons, genotoxic and carcinogenic constituents such as tar, nicotine, aromatic amines, nitrosamines, alkenes, and metals. The components of tobacco smoke exert their biological effects through interaction of reactive intermediates with DNA to form DNA adducts and further induce DNA damage [2].

Benzo(a)pyrene (BaP), a potent inducer of carcinogenesis and an important component of tobacco smoke is a representative compound of polycyclic aromatic hydrocarbons (PAHs) which shows cytotoxity and/or genotoxity in lung, stomach, and skin of the body. It is catalyzed by cytochromes P450 including CYP 1A1 and CYP 1B1 to form BaP-7, 8-diol which is activated to catechol, the auto-oxidation of which can generate reactive oxygen species (ROS) that cause oxidative DNA damage [3]. The major mechanisms for metabolic activation of BaP include formation of BaP-quinones (BPQs) that are important redox-cycle compounds, produced by a one-electron oxidation whose toxicity may be mediated to ROS such as superoxide anion, $\mathrm{H}_{2} \mathrm{O}_{2}$ and hydroxyl radical $(\bullet \mathrm{OH})$ that chemically attack nucleotides, proteins, carbohydrates, and fatty acids.
These are neutralized by the antioxidant enzymes superoxide dismutase (SOD), catalase (CAT), glutathione peroxidase (GPx), and xenobiotic reactivity decreased through the conjugation of reduced glutathione (GSH), catalyzed by GSH S-transferase. When the rate of elimination by antioxidative systems is slower than the rate of ROS production, lipid peroxidation (LPO) and DNA damage may occur leading to oxidative stress and subsequent canceration [4]. BaP has been detected in the cervical mucus of women [5] whose mechanism of oxidative damage on cervical tissue is rarely reported. Measurements of oxidative stress may provide further insight into cervix impairment induced by $\mathrm{BaP}$ in vivo.

An antioxidant is a molecule that delays the oxidation of proteins, carbohydrates, lipids, DNA and can be classified as the first line defense antioxidants which include SOD, CAT, GSH reductase, selenium, copper and zinc, the second line defense antioxidants which include GSH, vitamin C, albumin, vitamin E, carotenoids, flavonoids, and the third line defense antioxidants include a complex group of enzymes such as lipase, protease, DNA repair enzymes, transferases, methionine sulphoxide reductase for repair of damaged DNA, proteins, oxidized lipids, and peroxides. An effective antioxidant complex has various types of radical catching antioxidant sites that seek and destroy free radicals at many cellular sites thus helping in overall anti-oxidative capacity of cells and towards maintaining the health of biological tissues [6].

Curcuma amada, commonly known as Mango ginger, is a unique spice having morphological resemblance with ginger (Zingiber officinale) but imparts raw mango (Mangifera indica) flavor and is reported to contain 
ocimene, dihydro-ocimene, $\alpha$-pinene, $\alpha$-curcumene, $\beta$-curcumene, linalool, cuminyl alcohol, keto-alcohol, camphor, turmerone, linalyl acetate, safrole, curcumin, myristic acid, car-3-ene, myrcene, 1,8-cineol, limonene and perillene. The rhizome of the plant has been used for centuries in traditional medicine and is known to have cancer preventive or therapeutic capabilities by suppressing multiple signaling pathways and inhibit cell proliferation, invasion, metastasis and angiogenesis [7]. Its safety combined with its low cost and multiple targeting potential makes C. amada an ideal agent to be explored for prevention and treatment of various cancers and fits very well as a candidate for chemoprevention by edible phytochemicals [8]. Hence, this study is focused to evaluate the antioxidant and chemotherapeutic potential of ethanol extract of $C$. amada rhizome by assessing the antioxidants, serum markers, membrane-bound enzymes, and histopathological analysis in Sprague Dawley rats.

\section{METHODS}

\section{Chemicals}

BaP was obtained from Sigma Chemical Co. (St. Louis, USA). Corn oil used as vehicle for $\mathrm{BaP}$ and all other chemicals utilized were obtained from reputed local firms (India) and were of highest purity grade.

\section{Collection of plant sample}

Fresh rhizomes of $C$. amada were collected from local market of Coimbatore and were authenticated by G.V.S. Murthy, Scientist " $F$ " and Head, Center of Botanical Survey of India - Tamil Nadu Agricultural University, Coimbatore, Tamil Nadu, India where the herbarium voucher (BSI/SRC/5/23/201314/Tech/544) have been kept identifying the plant species.

\section{Extraction of plant material}

Freshly collected rhizomes were cleaned to remove adhering dust and were cut into pieces, shade dried at room temperature and subjected to size reduction to a coarse powder using Laboratory Willey Mill (Secor Make). Ethanol extract of rhizome was prepared using soxhlet apparatus, dried in rotary evaporator and used for the study.

\section{Selection of animals}

Adult female Sprague Dawley rats $(150-200 \mathrm{~g})$ purchased from KMCH College of Pharmacy, Coimbatore was used for the study. All animals were housed in polypropylene cages containing paddy husk as bedding under standard conditions of humidity (35-60\%), temperature $\left(25 \pm 2^{\circ} \mathrm{C}\right)$, and $12 \mathrm{hrs}$ light-dark cycle. They were allowed free access to standard pelleted diet throughout the experiment. The study was conducted in accordance with the guidelines of the Institutional Animal Ethics Committee at KMCH College of Pharmacy, Coimbatore, Tamil Nadu, India (Approval No: KMCRET/PhD/10/2013-2014).

\section{Experimental design}

$\mathrm{BaP}$ was dissolved in corn oil shortly before oral gavage. The animals were randomly divided into 5 groups (containing 6 animals each) namely control group, $\mathrm{BaP}$ group, $\mathrm{BaP}+$ cisplatin group, $\mathrm{BaP}+C$. amada (low dose) group, and $\mathrm{BaP}+C$. amada (high dose) group. All rats except control group were given $\mathrm{BaP}$ for induction of cervical cancer as described by Garry et al. [9], with minor modifications.

Briefly, each rat was orally administered with $10 \mathrm{mg} \mathrm{BaP} / \mathrm{kg}$ in $0.2 \mathrm{ml}$ corn oil, twice a week for 8 weeks (a total of $16 \mathrm{BaP}$ instillations per rat). The animals of $\mathrm{BaP}+$ cisplatin group were post-treated with cisplatin (10 $\mathrm{mg} / \mathrm{kg}$ b.wt.) for 4 weeks (daily) by intravenous administration. Rats of $\mathrm{BaP}+C$. amada (low dose) group and $\mathrm{BaP}+C$. amada (high dose) group were post-treated with $250 \mathrm{mg} / \mathrm{kg}$ b.wt. of ethanol extract of C. amada (orally) for 4 weeks (daily) and $500 \mathrm{mg} / \mathrm{kg}$ b.wt. of ethanol extract of $C$. amada (orally) for 4 weeks (daily), respectively.

\section{Collection of blood and tissue samples}

At the end of treatment period, the animals were anesthetized, blood collected from retro-orbital sinus, serum separated and used for antioxidant and marker assays. Cervical tissues were dissected out immediately and transferred to ice-cold saline for the tissue analysis.

\section{Preparation of homogenate}

About 10\% tissue homogenate was prepared using $0.1 \mathrm{M}$ Tris-buffer (pH 7.4) and used for estimation of antioxidants and membrane-bound enzymes.

\section{Determination of tumor burden}

All the animals except in control group were treated with BaP for 8 weeks (twice a week). At the end of the experimental regime, the rats were anesthetized using chloroform; cervical tissues were dissected out, split longitudinally and carefully observed under dissecting microscope for the presence of tumors. The number of nodules were counted and expressed as number of polyps.

\section{Estimation of SOD}

SOD activity was determined by Das et al. [10]. Pipetted $1.4 \mathrm{ml}$ aliquot of the reaction mixture in a test tube containing $1.1 \mathrm{ml}$ phosphate buffer, $75 \mu \mathrm{l}$ methionine, $40 \mu \mathrm{l}$ triton X-100, $75 \mu \mathrm{l}$ hydroxylamine hydrochloride, and $100 \mu \mathrm{l}$ ethylenediamine tetraacetic acid (EDTA). $100 \mu \mathrm{l}$ of the sample was added followed by preincubation at $37^{\circ} \mathrm{C}$ for 5 minutes. $80 \mu \mathrm{l}$ of riboflavin was added, and the tubes were exposed for 10 minutes to $200 \mathrm{~W}$ Philips fluorescent lamps. The control tube contained an equal amount of buffer instead of sample. The sample and its respective control were run together. At the end of the exposure time, $1.0 \mathrm{ml}$ of Greiss reagent was added to each tube, and the absorbance of the color formed was measured at $543 \mathrm{~nm}$. One unit of enzyme activity was defined as the amount of SOD capable of inhibiting $50 \%$ of nitrite formation under assay condition.

\section{Estimation of CAT}

The activity of CAT was measured by Sinha [11]. To $0.9 \mathrm{ml}$ of phosphate buffer, $0.1 \mathrm{ml}$ of serum/tissue homogenate, $0.4 \mathrm{ml}$ of hydrogen peroxide were added. At time $0 \mathrm{~s}$ and at $60 \mathrm{~s}$ after the addition of the serum/ homogenate, $2.0 \mathrm{ml}$ of dichromate-acetic acid mixture was added. The tubes were kept in boiling water bath for 10 minutes and the color developed was read at $620 \mathrm{~nm}$. Standards in the range of 1.2-6.0 $\mu \mathrm{mol}$ were taken and processed as test and blank containing reagent alone. The activity of CAT was expressed as $\mu$ mole of $\mathrm{H}_{2} \mathrm{O}_{2}$ decomposed/ minutes/mg protein.

\section{Estimation of GPx}

GPx was measured by the method of Ellman [12]. To $0.4 \mathrm{ml}$ of buffer, $0.2 \mathrm{ml}$ of EDTA, $0.1 \mathrm{ml}$ of sodium azide and $0.2 \mathrm{ml}$ of reduced GSH, $0.1 \mathrm{ml}$ of $\mathrm{H}_{2} \mathrm{O}_{2}$ were added to two test tubes labeled as test (T) and control (C). To the test added $0.2 \mathrm{ml}$ of sample and to the control added $0.2 \mathrm{ml}$ of water. The contents were mixed well and incubated at $37^{\circ} \mathrm{C}$ for 10 minutes. The reaction was arrested with the addition of $0.5 \mathrm{ml}$ of $10 \%$ trichloroacetic acid (TCA). To determine the GSH content, $1.0 \mathrm{ml}$ of supernatant was removed by centrifugation. To that $3.0 \mathrm{ml}$ of buffer and $0.5 \mathrm{ml}$ of Ellman's reagent, the color developed was read at $412 \mathrm{~nm}$. The activity was expressed in term of $\mu \mathrm{g}$ of GSH consumed/minutes $/ \mathrm{mg}$ protein.

\section{Estimation of total reduced GSH}

GSH activity was measured by Moron et al. [13] method. A known weight of tissue was homogenized in phosphate buffer. From this $0.5 \mathrm{ml}$ was pipetted out and precipitated with $2.0 \mathrm{ml}$ of $5 \%$ TCA. $1.0 \mathrm{ml}$ of supernatant/serum was taken after centrifugation and added $0.5 \mathrm{ml}$ of Ellman's reagent and $3.0 \mathrm{ml}$ of phosphate buffer. The yellow color developed was read at $412 \mathrm{~nm}$. Pipetted out $0.2-1.0 \mathrm{ml}$ standard solution corresponding to a $\mu \mathrm{g}$ of 40-200. The volume, in all the tubes, was made up to $1.0 \mathrm{ml}$ with distilled water. Then, added $0.5 \mathrm{ml}$ of Ellman's reagent and $3.0 \mathrm{ml}$ of phosphate buffer to all the tubes. The absorbance was read at $412 \mathrm{~nm}$ within 2 minutes against the reagent blank. The amount of GSH was expressed as $\mu \mathrm{g} / \mathrm{g}$ tissue.

\section{Estimation of ascorbic acid}

Ascorbic acid was measured by Omay et al. [14] method. $1.0 \mathrm{ml}$ of $10 \%$ homogenate was precipitated with 5\% ice-cold TCA and centrifuged for 20 minutes at 3500 g. $1.0 \mathrm{ml}$ of the supernatant/serum was mixed with 
$0.2 \mathrm{ml}$ of dinitrophenylhydrazine-thiourea-copper sulfate reagent and incubated for $3 \mathrm{hrs}$ at $37^{\circ} \mathrm{C}$. Then $1.5 \mathrm{ml}$ of ice-cold $65 \%$ sulfuric acid was added. Mixed well and the solutions were allowed to stand at room temperature for an additional 30 minutes. Absorbance was determined at $520 \mathrm{~nm}$. The results were expressed as $\mu \mathrm{g} / \mathrm{mg}$ protein.

\section{Estimation of lipid peroxidation}

Lipid peroxidation was determined by the method of Bishayee and Balasubramanium [15]. Pipetted out $1.0 \mathrm{ml}$ of tissue homogenate/ serum into a test tube labeled test and $1.0 \mathrm{ml}$ of water in test tube labeled "blank." Added $2.0 \mathrm{ml}$ of the thiobarbituric acid-TCA-Hcl reagent mixture to all test tubes. Mixed well and placed in boiling water bath for 5 minutes, cooled. Standards in the range of 20-100 $\mu \mathrm{g}$ were treated similarly. The absorbance of clear supernatant was measured against reference blank at $535 \mathrm{~nm}$.

\section{$\mathrm{Na}^{+} \mathrm{K}^{+}$adenosine triphosphatase (ATPase)}

Bonting [16] method of measuring the activity of $\mathrm{Na}^{+} \mathrm{K}^{+}$ATPase is based on the transport of $\mathrm{Na}^{+} \mathrm{K}^{+}$against concentration gradient at the cost of adenosine triphosphate ATP molecule liberating inorganic phosphate (Pi) that is estimated. To $1.0 \mathrm{ml}$ of Tris buffer, $0.2 \mathrm{ml}$ of each of $184 \mathrm{mM}$ Tris- $\mathrm{HCl}$ buffer ( $\mathrm{pH} 7.5$ ), $50 \mathrm{mM} \mathrm{MgSO}, 50 \mathrm{mM} \mathrm{KCl,} 600 \mathrm{mM} \mathrm{NaCl}$, $1 \mathrm{mM}$ EDTA and $40 \mathrm{mM}$ ATP were mixed together. The final assay mixture is a final volume of $2.0 \mathrm{ml}$, containing $92 \mathrm{mM}$ Tris-buffer, $5 \mathrm{mM}$ $\mathrm{MgSO}_{4}, 60 \mathrm{mMNaCl}, 1 \mathrm{mM}$ EDTA and $4 \mathrm{mM}$ ATP. After 10 minutes of equilibration at $37^{\circ} \mathrm{C}$ in an incubator, reaction was started by the addition of $0.1 \mathrm{ml}$ of tissue homogenate. The tubes were incubated for 15 minutes, and the reaction was arrested by the addition of $1.0 \mathrm{ml}$ of $10 \%$ TCA. The phosphorus content in the supernatant was estimated by Fiske and Subbarow method. The enzyme activity is expressed as micromoles of Pi liberated/minutes/mg protein.

\section{$\mathrm{Ca}^{+}$ATPase}

$\mathrm{Ca}^{+}$ATPase activity was estimated as described by Hjertén and Pan method [17] that measures the amount of inorganic phosphorus liberated. $1 \mathrm{ml}$ of each of $375 \mathrm{mM}$ Tris-HCl buffer (pH 7.6), $25 \mathrm{mM}$ $\mathrm{CaCl}_{2}, 10 \mathrm{mM}$ ATP were mixed well, $0.1 \mathrm{ml}$ of homogenate and $0.1 \mathrm{ml}$ of water were added, and was incubated for 15 minutes at $37^{\circ} \mathrm{C}$. The reactions were arrested by the addition of $1.0 \mathrm{ml}$ of $10 \%$ TCA. The control tubes received enzyme after the addition of $10 \%$ TCA. The phosphorous content in the supernatant was measured by the method of Fiske and Subbarow. The enzyme activity is expressed as micromoles of Pi liberated/minute/mg protein.

\section{$\mathrm{Mg}^{+}$ATPase}

The activity was estimated by the method of Ohnishi et al. [18] that involves the estimation of liberated inorganic phosphorus. The enzyme activity was estimated by the addition of $0.1 \mathrm{ml}$ of homogenate to an incubation medium containing $0.1 \mathrm{ml}$ of water and $0.1 \mathrm{ml}$ of each of 375 mMTris- $\mathrm{HCl}$ buffer (pH 7.6), $25 \mathrm{mM} \mathrm{MgCl}_{2}$ and $10 \mathrm{mM}$ ATP. The final concentration of tris buffer, $\mathrm{MgCl}_{2}$ and ATP were $75 \mathrm{mM}, 5 \mathrm{mM}$ and $2 \mathrm{mM}$, respectively, in the total incubation volume of $0.5 \mathrm{ml}$. The reaction was terminated after 15 minutes by the addition of $1.0 \mathrm{ml}$ of $10 \%$ TCA. The liberated Pi was estimated by the method of by Fiske and Subbarowand enzyme activity is expressed as micromoles of $\mathrm{Pi}$ liberated/minutes/mg protein.

\section{Serum cancer markers}

Specific cancer markers, carcinoembryonic antigen (CEA), gammaglutamyltransferase (GGT), and cancer antigen (CA) 125 were done using an automate analyzer DxC 860i (Beckman Coulter)

\section{Histopathological examination}

Formalin-fixed tissues were processed for Ehrlich's hematoxylin staining using conventional Laboratory procedure. Briefly, the tissues were dehydrated through ascending grades of Isopropyl alcohol, cleared in xylene, and embedded in low melting point paraffin blocks. Sections of 3 micron thickness were cut, placed serially on clean glass slides and then deparaffinized by immersing in xylene. Three contiguous sections were made from each cervical tissue and stained with Ehrlich's hematoxylin for evaluation under Labomed binocular light microscope with ultra scope 9.1. Cervical cell injury and other aspects were observed under high power dry objective $(\times 40)$.

\section{Statistical analysis}

The results were expressed as mean \pm standard error of the mean and analyzed by using one-way ANOVA followed by Dunnett's multiple comparison tests. Data was computed for statistical analysis by using GraphPad Prism version 5.00 for Windows, GraphPad Software, San Diego California, USA, and compared with the vehicle control group. $p$ values $(p<0.05)$ were considered statistically significant.

\section{RESULTS}

\section{Tumor burden}

Tumor burden was significantly $(\mathrm{p}<0.001)$ increased in BaP-induced rats that are indicated as number of polyps when compared to control animals that lack the polyps. Cisplatin treatment decreased the number of polyps compared to induced group. Administration of $250 \mathrm{mg} / \mathrm{kg}$ b.wt. of C. amada rhizome decreased the number of polyps at $\mathrm{p}<0.001$ level while administration of $500 \mathrm{mg} / \mathrm{kg}$ b.wt. of rhizome decreased the number of polyps at $\mathrm{p}<0.01$ compared to control group (Fig. 1)

\section{Antioxidants in serum and tissue}

Overproduction of ROS can cause severe impairment of cellular functions and necrotic lesions in the cervical tissue of animals. Antioxidants may protect against this toxicity by the preventing their formation [19]. Fig. 2 represents the significant decrease $(p<0.001)$ of serum antioxidants in BaP induced rats. Treatment with standard drug cisplatin increased the antioxidants activities compared to induced group. Administration of rhizome extract $(250 \mathrm{mg} / \mathrm{kg}$ b.wt.) reverted SOD, CAT activities at $\mathrm{p}<0.001$ level and GPx at $\mathrm{p}<0.01$ level compared to control. $500 \mathrm{mg} / \mathrm{kg}$ b.wt. of rhizome extract reversed SOD and CAT at $\mathrm{p}<0.001$ level and non-significantly reverted GPx, GSH, and vitamin C level compared to control group.

Activities of cervical tissue antioxidants were found to be decreased significantly at $\mathrm{p}<0.001$ level in BaP induced rats (Fig. 3). Treatment with cisplatin increased the activities of antioxidants compared to induced group. $250 \mathrm{mg} / \mathrm{kg}$ b.wt. of rhizome extract significantly $(\mathrm{p}<0.001)$ reverted SOD and vitamin $\mathrm{C}$ activities and non-significantly increased the activities of CAT, GP, and GSH compared to control. Administration with $500 \mathrm{mg} / \mathrm{kg}$ b.wt. of rhizome extract reversed the activities of SOD activity at $\mathrm{p}<0.01$, CAT, GSH at $\mathrm{p}<0.001$ level and nonsignificantly reverted GPx, and vitamin C compared to control group.

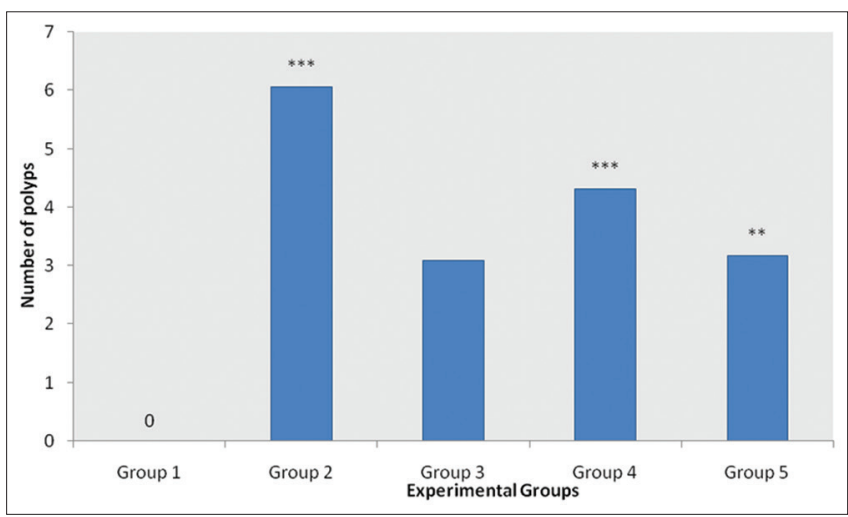

Fig. 1: Effect of ethanol extract of Curcuma amada rhizome on Tumor burden of Experimental animals. Values are Mean \pm SEM $(\mathrm{n}=6) .{ }^{* * *} \mathbf{p}<0.001$ : Extremely Significant, ${ }^{* *} \mathbf{p}<0.01$ : Highly Significant 


\section{Lipid peroxidation}

BaP significantly $(\mathrm{p}<0.001)$ increased LPO in serum and tissue of rats while cisplatin treatment non-significantly decreased LPO compared to control group. Treatment with $C$. amada rhizome nonsignificantly reduced LPO compared to normal (Fig. 4).

\section{Membrane-bound enzymes}

The disturbance in ionic homeostasis in cervical cancer patients may result from elevated LPO resulting in increased membrane permeability [20]. The elevation of membrane-bound enzymes activities (Fig. 5) in tissues of BaP-induced rats indicate the deteriorating effect of BaP on the animals. Cisplatin treatment significantly reduced $\mathrm{Na}^{+} \mathrm{K}^{+}$ ATPase and $\mathrm{Ca}^{2+}$ ATPase activity at $\mathrm{p}<0.01$ and $\mathrm{Mg}^{2+}$ ATPase activity at $\mathrm{p}<0.001$ level compared to control. Treatment with $250 \mathrm{mg} / \mathrm{kg}$ b.wt. of C. amada rhizome extract significantly reverted $\mathrm{Na}^{+} \mathrm{K}^{+}$ATPase activity at $\mathrm{p}<0.05$ and $\mathrm{Mg}^{2+}$ ATPase activity at $\mathrm{p}<0.001$ level $0.500 \mathrm{mg} / \mathrm{kg}$ b.wt. of $C$. amada rhizome extract non-significantly reverted the enzyme activities to near normal.

\section{Serum markers}

Enzymes that are present in much higher concentration inside the cell are released into the systemic circulation as the result of tumor necrosis or a change in the membrane permeability of the cells that signal the presence of malignancy. Fig. 6 shows the significant increase $(\mathrm{p}<0.001)$ of tumor cancer markers in BaP-induced group. Treatment with cisplatin reduced the level of markers compared to control $0.250 \mathrm{mg} / \mathrm{kg}$ b.wt. of rhizome extract significantly reduced the markers at $0.01 \%$ while $500 \mathrm{mg} / \mathrm{kg}$ b.wt. of rhizome extract non-significantly reduced the serum markers compared to control rats.

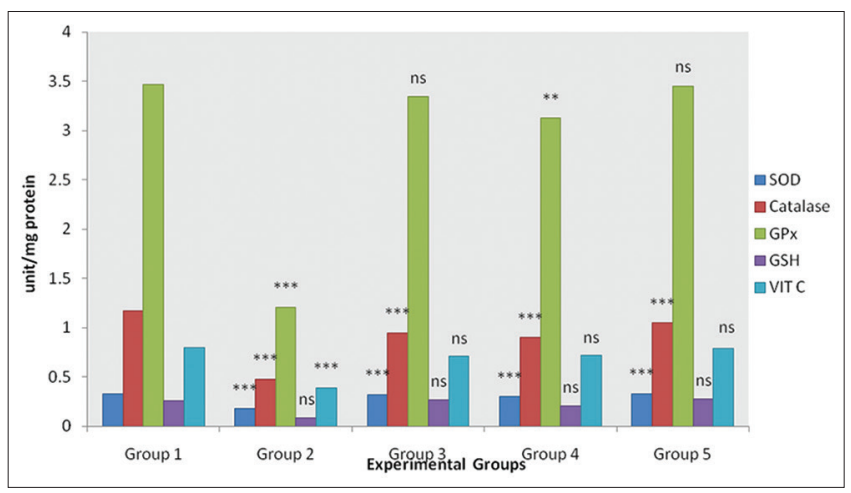

Fig. 2: Effect of ethanol extract of Curcuma amada rhizome on Antioxidants in serum of Experimental animals. Values are Mean \pm SEM $(\mathrm{n}=6) .{ }^{* * *} \mathrm{p}<0.001$ : Extremely Significant, ${ }^{* *} \mathrm{p}<0.01$ : Highly Significant. ns: non-significant

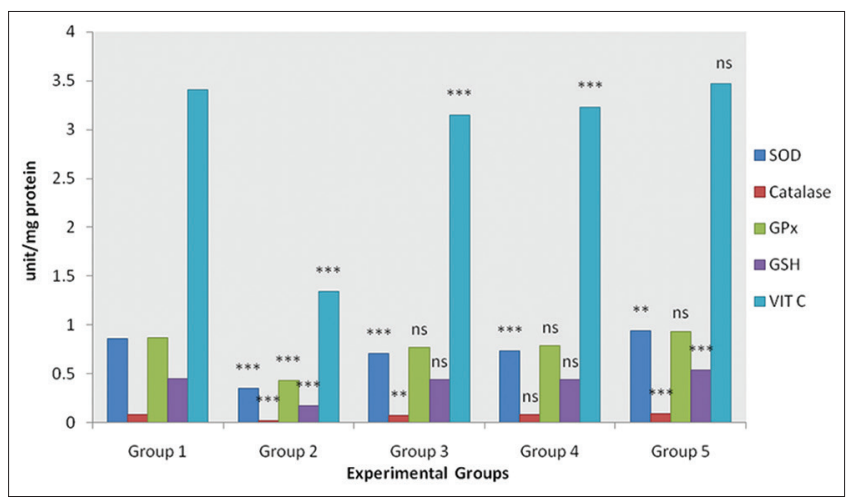

Fig. 3: Effect of ethanol extract of Curcuma amada rhizome on Antioxidants in Cervical Tissue of Experimental animals. Values are Mean \pm SEM $(\mathrm{n}=6) .{ }^{* * *} \mathrm{p}<0.001$ : Extremely Significant, ${ }^{* *} \mathbf{p}<0.01$ : Highly Significant. ns: non-significant

\section{Histopathological evaluation}

The effect of BaP induced cervical carcinogenesis was also apparent by histological examination. Fig. 1 shows Ehrlich's hematoxylin stained cervical epithelial tissue. In control group of rats, cervical epithelium had normal architecture (Fig. 7a). In BaP induced rats the cervical tissue showed confluent necrosis leading to cervical dysplasia and Stage-I cervical intraepithelial neoplasia (CIN) with individual cells round to polygonal with moderate eosinophilic cytoplasm and round to vesicular nuclei with some showing nucleoli (Fig. 7b). Administration of cisplatin reduced necrosis in cervical tissue of experimental animals (Fig. 7c). Rats treated with $250 \mathrm{mg} / \mathrm{kg}$ b.wt. of C. amada showed minimal changes in architecture imparting the treatment effect on features of chronic cervicitis (Fig. 7d). Treatment with $500 \mathrm{mg} / \mathrm{kg}$ b.wt. of C. amada reverted the normal architecture of cervical tissue that showed the anticancer potential of phytochemicals present in the extract (Fig. 7e).

\section{DISCUSSION}

Cervix carcinoma is one of the leading causes of mortality and important public health problem worldwide, particularly in the developing countries and accounts for $80-85 \%$ of all the female genital tract malignancies [21]. Epidemiological studies have implicated that cigarette smoking is an independent risk factor for the development of cervical cancer. since it contains a complex mixture of nicotine, cotinine, $\mathrm{BaP}$ and 4-(N-methyl-N-nitrosamino)-1-(3-pyridyl)-1-butanone, the potent inducers of carcinogenesis [22]. The present study has been carried out to investigate the antioxidant and chemotherapeutic potential of C. amada rhizome extraction BaP induced cervical carcinoma in female SD rats.

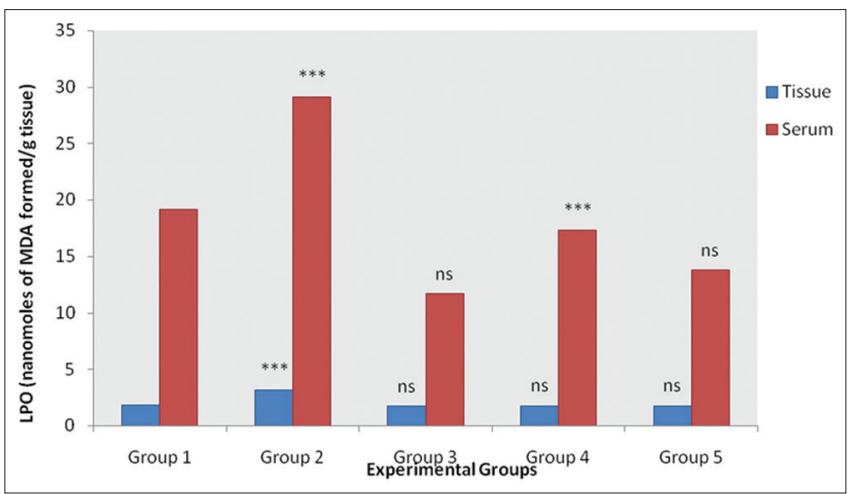

Fig. 4: Effect of ethanol extract of Curcuma amada rhizome on Lipid Peroxidation of Experimental animals. Values are Mean \pm SEM ( $\mathrm{n}=6) .{ }^{* * *} \mathbf{p}<0.001$ : Extremely Significant, $\mathrm{ns}$ : non-significant

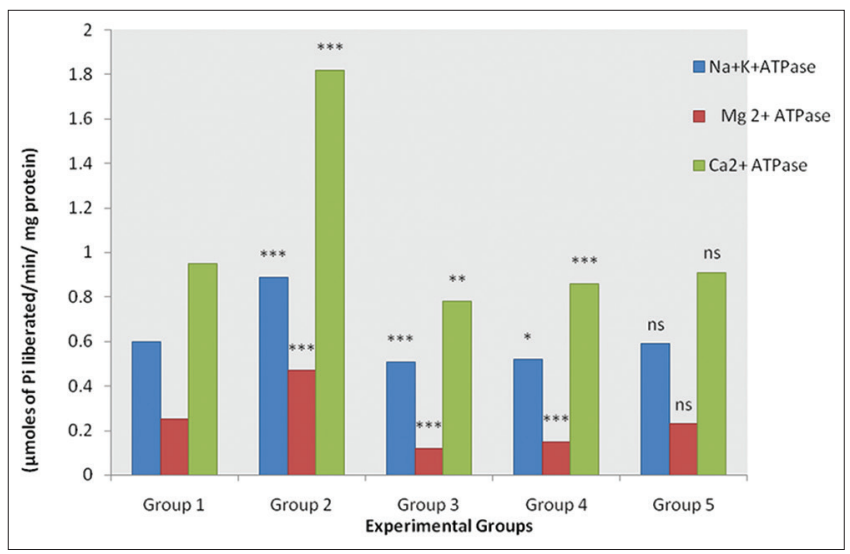

Fig. 5: Effect of ethanol extract of Curcuma amada rhizome on Membrane bound enzymes of Experimental animals. Values are Mean \pm SEM $(n=6) .{ }^{* * *} p<0.001$ : Extremely Significant, ${ }^{* *} p<0.01$ : Highly Significant, ns: non-significant 
$\mathrm{BaP}$, an extremely potent pro-carcinogen, is metabolized by cytochrome P-450 based mono-oxygenase system, the major phase I biotransformation enzyme to a variety of carcinogenic metabolites that are responsible for initiating tumor genesis. BaP-metabolites may directly form ROS through redox cycling or disrupt mitochondrial electron transport leading to formation of more ROS including superoxide anions, hydroxyl radicals and hydrogen peroxide that play a vital role in initiating and progressing oxidative stress that cause peroxidation damage to lipids resulting in damage of organelle and cellular membrane. An increased rate of ROS production occurs in highly proliferative cancer cells, owing to the presence of oncogenic mutations that promote aberrant metabolism. Increased oxidative stress is well documented in transformed cells [23] and growing evidence suggests that ROS act as second messengers in intracellular signaling cascades which induce and maintain the oncogenic phenotype of cancer cells [24].

Since $\mathrm{BaP}$ is an environmental pollutant and is believed to be a risk factor for human chemical carcinogenesis, it is important to identify the naturally occurring agents that could modulate BaPinduced tumorigenesis. Most of the synthetic drugs available today are cytotoxic, immunosuppressant and may cause a variety of side effects in the normal organs of the body [25]. Since natural sources play a vital role in cancer prevention and treatment, the antitumor agents currently used in the medicine are of natural origin [26].

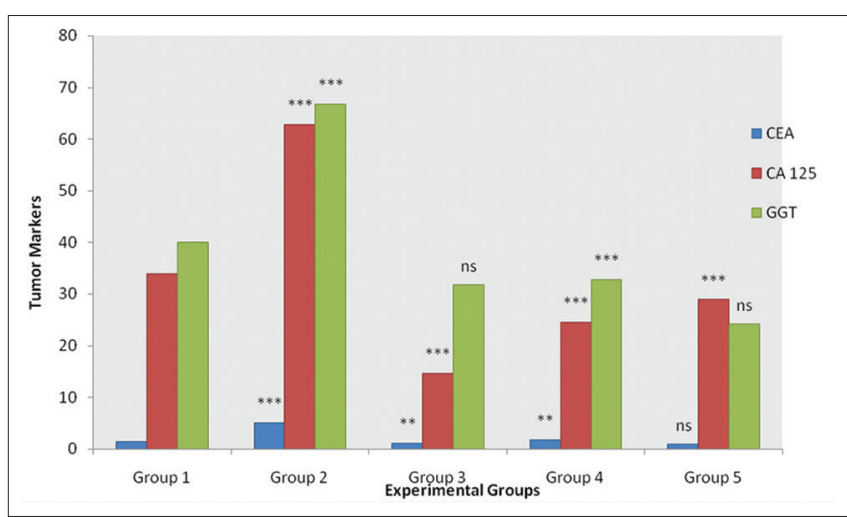

Fig. 6: Effect of ethanol extract of Curcuma amada rhizome on Tumor Markers of Experimental animals. Values are Mean \pm SEM $(\mathrm{n}=6) .{ }^{* * *} \mathrm{p}<0.001$ : Extremely Significant, ${ }^{* *} \mathrm{p}<0.01$ : Highly Significant, ns: non-significant
Recent progress in molecular biology and pharmacology enhances natural phytochemicals derived from medicinal plants that have gained significant recognition in the potential management of several human clinical conditions, including cancer. Secondary metabolites like polyphenols, terpenoids like limonene [27] and flavonoids have been reported to possess antioxidant, antimutagenic and anticancer properties in many studies because of their unique pharmacophores and medicinal properties. They may act as antioxidants, nutrient protectors and also responsible for the prevention and treatment of radical-mediated disorders. The preventive mechanisms of tumor promotion by these phytochemicals range from inhibition of genotoxic effects, increased antioxidants and anti-inflammatory activity, inhibition of proteases and cell proliferation, protection of intracellular communications to modulate apoptosis and signal transduction pathways [28].

C. amada, popularly known as mango ginger, is a perennial, rhizomatous spice, belonging to Zingiberaceae family. It is found wild as well as in cultivation in various parts of world, used in food industry as basic ingredient in pickles, preserves, candies, sauces, curries, salads and also medically as coolant, astringent and to promote digestion. Its rhizome has been traditionally used for healing of wounds, cuts, itching and used against scabies, lumbago, stomatitis, inflammation in the mouth and ear, ulcers on the male sex organs [29]. It possesses antifungal, antiinflammatory, analgesic, anticancer, antihyperglyceridemia [30], and carminative properties [31]. The rhizome extracts were observed to be potent antimutagen based on its antioxidative activity [32].

Comparison of tumor burden between control and BaP treated animals revealed that $\mathrm{BaP}$ induction caused significant tumor burden leading to tumor genesis. Treatment with C. amada rhizome extract significantly reduced tumor burden that indicates its anticancer efficacy. This is in accordance with the statement that the reliable criterion for judging the potency of an anticancer drug is the prolongation of the life span of tumor-bearing animals [33].

Antioxidant status has been suggested as a useful tool in estimating the risk of oxidative damage induced carcinogenesis. The antioxidative defense systems that include antioxidant enzymes like SOD, CAT, GPx simultaneously neutralize chemical reactive intermediates produced by endogenous pathways and/or xenobiotic metabolism [34]. SOD detoxifies superoxide radicals to hydrogen peroxide, CAT decomposes hydrogen peroxide to water and oxygen and GPx converts peroxides and hydroxyl radicals into non-toxic forms [35]. GSH constitutes the first line of defense against free radicals and plays an important role in

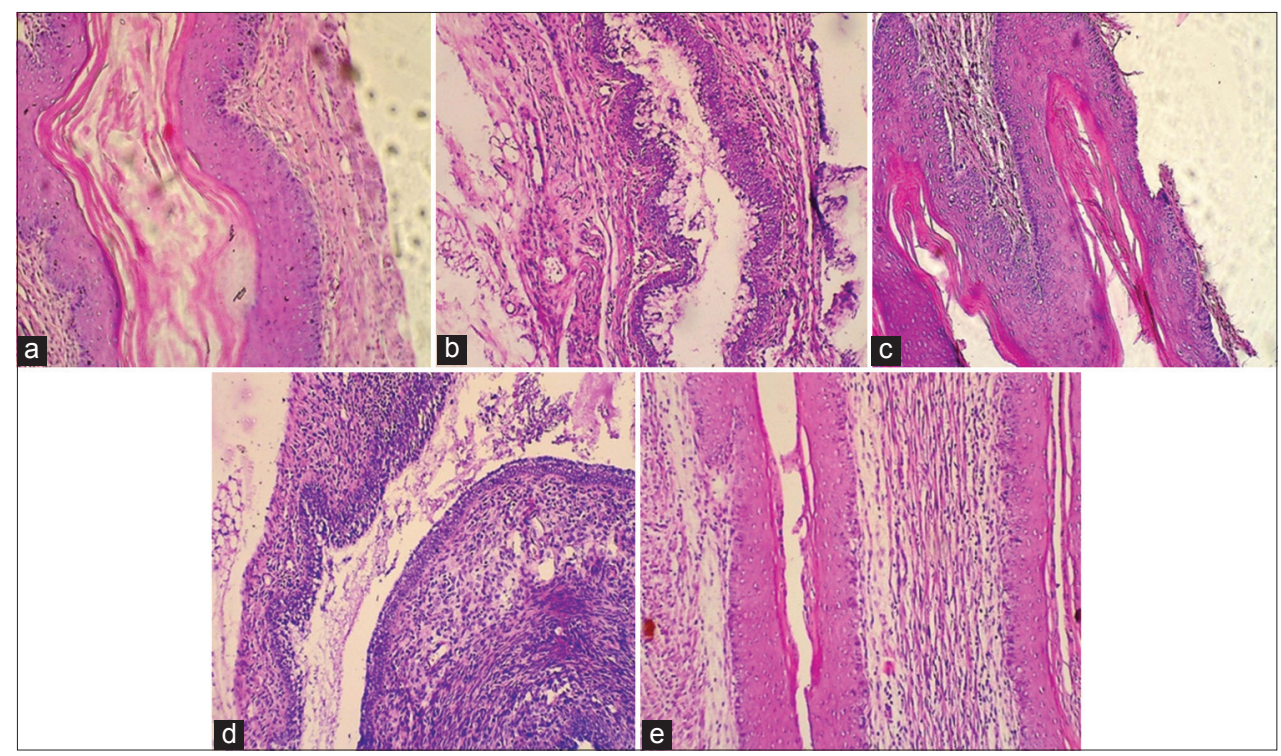

Fig. 7: (a-e) Histological changes of benzo(a)pyrene induced cervical cancer in experimental animals 
the detoxification of electrophilic substances and prevention of cellular oxidative stress [36]. Several studies have shown that many radical scavengers, including naturally occurring compounds such as vitamin C, have been found to possess a strong antioxidant activity related to a strong scavenging capacity [37].

Studies show that serum of patients with CIN and carcinoma of the cervix evidenced changes in impairment of either enzymatic or nonenzymatic antioxidant systems [38]. In the present study, we observed significantly lowered activities of serum and tissue SOD, CAT, GPx, GSH and vitamin $\mathrm{C}$ in $\mathrm{BaP}$ induced rats when compared with those of the control group that was caused by the neoplastic cells that sequestered essential antioxidants from circulation to supply the demands of growing tumor [39]. Reduced tissue antioxidants were due their leakage from the cytoplasm caused by peroxidative damage of lipids that confirms the severe oxidative stress status of the cervical tissue. Ramakrishnan et al. [40] cited decreased SOD activities, Vinodhkumar et al., [41] showed decreased CAT in various carcinogenic conditions that may be due to the increased LPO. Decline in GPx activity may be attributed to the reduction in the levels of reduced GSH and increase in the level of peroxides during carcinogenesis [42]

Treatment with standard drug cisplatin increased activities of antioxidants in serum and tissue of experimental animals. Administration of low and high dose of $C$. amada rhizome extract significantly reverted serum and tissue SOD and CAT activities and non-significantly reverted the activities of GPx, GSH and vitamin C that may be caused by the presence of phytochemicals like phenolic compounds [43] in the extract that act as natural antioxidant due to their redox properties and plays an important role in adsorbing and neutralizing free radicals, quenching singlet and triplet oxygen or decomposing peroxides [44], flavonoids like gallic acid [45] that inhibit cancer cell growth and plays an important role in the prevention of malignant transformation and cancer development by acting as a free radical scavenger and an inducer of differentiation and apoptosis in leukemia, lung cancer, colon adenocarcinoma cell lines and in normal lymphocyte cells [46], terpenoids like difurocumenonol, amadannulen and amadaldehyde that scavenge the damaging reactive oxygen species such as hydroxyl radicals, peroxyradicals, superoxide anion that are known to be involved in inflammation and carcinogenesis [47] by their radical scavenging activities [48] and curcuminoids like curcumin has been shown to suppress transformation, proliferation, and metastasis of tumors [49]. This is in accordance with [50] who stated that regular consumption of fruits and vegetables is strongly associated with reduced risk of developing chronic diseases such as cancer as the phytochemical extracts from it exhibit strong antioxidant activity. The result is also supported by many studies that were conducted (in vitro) in various extracts of the rhizome like aqueous [51], methanol [52], chloroform [53], petroleum ether, ethyl acetate and ethanol [54] that exhibited antioxidant activity. Recently an inverse association between antioxidant nutrients and cervical cancer was shown suggesting protective effect of natural extract against cervical dysplasia [55].

Numerous reports have documented that LPO is an important parameter in evaluating the level of oxidative stress in organisms [56]. $\mathrm{BaP}$ is a very effective carcinogen with a capability to induce enormous amounts of free radicals, which in turn reacts with lipids causing LPO, the products of which include malondialdehyde that has been reported to be involved in the formation of tumors [57]. In this study, $\mathrm{BaP}$ induction caused generation of excessive free radicals leading to significant increase of LPO level in serum and tissue of rats. Pan et al. [58] had reported an increase of LPO after exposure to BaP and the concentration changes of BPQs metabolites in the body. Increase of tissue LPO in BaP treated groups indicated that the cervix suffered from severe and continuous LPO caused by the free radicals that participate in BaP epoxidation [59]. Treatment with C. amada rhizome significantly reduced LPO in rats when compared to cisplatin treatment that would be caused by the presence of terpenoids in the extract that exerted LPO inhibitory activity and curcumin that suppressed LPO induced tissue inflammation [60]. The present result correlates with report stating that non-polar extracts showed good LPO inhibitory activity [61].

Assay of membrane-associated enzyme activities indicate the alterations of the membrane under diseased status. ATPases are intimately associated with plasma membrane and participates in energy requiring translocation of sodium, potassium, calcium, and magnesium. Higher level of LPO process ultimately impairs the membrane function by decreasing its fluidity and altering the activities of membrane-bound enzymes and receptors [62]. $\mathrm{Na}^{+} \mathrm{K}^{+}$ATPase is a ubiquitously expressed integral membrane protein that carries out the extrusion and uptake of $\mathrm{Na}^{+}$and $\mathrm{K}^{+}$ions across the plasma membranes of cells and is critical in maintaining physiological electrochemical gradient that is essential for cell survival and activities. Alterations in $\mathrm{Na}+\mathrm{K}+-$ ATPase alters the $\mathrm{Na}+/ \mathrm{Ca} 2+$ exchange mechanism which may play a vital role in regulating the cellular calcium levels. $\mathrm{Ca}^{2+}$ ATPase, the best characterized pumps that have been linked to cancer are important regulators of intracellular calcium concentration that enable muscle contraction, relaxation and control calcium signaling pathways [63]. $\mathrm{Mg}^{2+}$ ATPase is believed to be responsible for control of membrane permeability and maintain intracellular $\mathrm{Mg}^{2+}$, changes of which can control protein synthesis and cell growth [64]. This study shows significant elevation of these enzyme activities in tissues that may be due to peroxidation of membrane lipids that alters the lipid milieu, leading to alterations in membrane fluidity and cell deformability [65] that indicate the persistent deteriorating effect of BaP in cancer-bearing animals. Kolanjiappan et al. [66] had reported elevated $\mathrm{Na}^{+} \mathrm{K}^{+}$ATPase activity in erythrocytes of cervical cancer patients and [67] reported elevated activity of $\mathrm{Ca}^{2+}$ ATPase and $\mathrm{Mg}^{2+}$ ATPase in BaP induced toxicity of experimental mice. Treatment of experimental rats with cisplatin significantly reduced the activities of these enzymes. Post-treatment of low dose rhizome extract significantly decreased the enzyme activities by protecting the "SH" groups of enzymes from the oxidative damage through the inhibition of peroxidation of membrane lipids [68]. Minimizing the alterations in the activities of these enzymesindirectly indicates the membrane stabilizing action of $C$. amada rhizome extract in $\mathrm{BaP}$ induced cervical carcinogenesis of experimental rats.

Analysis of tumor marker enzymes serves as an indicator of cancer response to environment. Distribution of many biochemical, immunological and molecular properties of the host have been observed in BaP mediated cancer conditions [69]. With this concept, the cancer specific markers CEA, CA 125 and GGT were evaluated in the present study. CEA is a glycoprotein, the elevated levels of which are found in smokers [70] and cervical cancer patients [71]. The enhanced marker level in BaP induced animals indicates the correlation that exists between CEA and tumor burden. This elevation was significantly inhibited by low dose of rhizome extract that may be caused by curcumin that inhibited tumor initiation by decreasing cytochrome P450 and aryl hydrocarbon hydroxylase activity with a concomitant decrease in BaP-DNA adduct in cells treated with BaP [72], as that of standard drug cisplatin.

CA 125, a membrane glycoprotein is the potential tumor marker of cervical cancer. Raised CA 125, associated with the stage of cervical disease is of some prognostic significance and has been detected in patients with newly diagnosed carcinoma of the cervix, squamous cell cervical cancer, cervical adenocarcinoma and are associated with advanced tumor stage, large tumor size, high histological grade, lymph-vascular space involvement, deep cervical stromal invasion and lymph node involvement [73]. The elevation of this marker correlates with the intraepithelial neoplastic lesions that were observed in histology of rats treated with BaP. A significant decrease of CA 125 was observed in rats treated with low dose of rhizome extract when compared to that of cisplatin treatment which may be due to the presence of terpenoids that act at various stages of tumor development, inhibit initiation and promotion of carcinogenesis, induce tumor cell differentiation and apoptosis and suppress tumor angiogenesis, invasion and metastasis through regulation of various transcription and growth factors as well as intracellular signaling mechanisms [74] 
GGT, the marker of pathologic oxidative stress in cancer patients is a key enzyme that catalyzes the transfer of the glutamyl moiety linked through glutamate gamma carboxylic acid to cysteine favoring the recovery of constituent amino acids for subsequent intracellular GSH resynthesis and has been traditionally regarded as a component of the cell protection system against oxidative stress whose dysregulated expression has been detected in several tumor types [75]. In the present study, BaP induction elevated the GGT level in Group II rats that reflected the malignant cell transformation and tumor burden in carcinoma of the cervix [76]. Treatment with low dose of rhizome extract significantly reverted the marker level to near normal level when compared to control group that would be due to the presence of curcuminoids in the extract that induced repair of DNA oxidative damage and chromosomal aberrations [77] caused by BaP metabolism.

In the histological examination, a series of pre-cancerous lesions were observed in cervices of BaP-treated group, showing that BaP can cause different injuries to the cervical tissue epithelium [78]. As the crude therapeutic preparations are more effective and less toxic than the isolated active components or their respective synthetic counterparts because they contain the total family of medicinal compounds just as they are found in their natural source and hence offer less risk of side effects the treatment with rhizome extract rectified the cervical lesions induced by $\mathrm{BaP}$ in the experimental rats.

\section{CONCLUSION}

BaP, a prototypical PAHs is a widespread environmental pollutant and thought to be one of the etiological factors in human chemical carcinogenesis. Since experimental carcinogenesis and modulatory action on antioxidant enzymes help to evaluate the chemotherapeutic potential of natural products, in this study, we screened the potential of ethanol extract of $C$. amada rhizome on BaP-induced cervical carcinogenesis in female Sprague Dawley rats. The extract significantly $(\mathrm{p}<0.001)$ increased serum and cervical tissue antioxidant activity, inhibited LPO in serum and tissue, decreased membrane-bound enzymes and tumor markers that may be caused by the presence of active components in the crude extract that might have facilitated the detoxification and excretion of oxidized metabolites of BaP by acting as synergists for the therapeutic effects. The findings of the present investigation support this extract to be an effective anticancer agent, therefore triggering for preclinical studies and pharmacokinetic profiling to determine its mechanism of action and clinical doses for human population.

\section{ACKNOWLEDGMENT}

The authors thank Mr. G. Arihara Sivakumar, Associate Professor, KMCH College of Pharmacy, Coimbatore, for the guidance and support rendered by him for successful completion of the study.

\section{REFERENCES}

1. Brys M, Semczuk A, Wójcik M, Krajewska WM, Jakowicki JA. p53 protein detection by the western blotting technique in normal and neoplastic specimens of human endometrium. Cancer Lett 2000;148(2):197-205.

2. Thielen A, Klus H, Müller L. Tobacco smoke: Unraveling a controversial subject. Exp Toxicol Pathol 2008;60(2-3):141-56.

3. Park JH, Mangal D, Frey AJ, Harvey RG, Blair IA, Penning TM. Arylhydrocarbon receptor facilitates DNA strand breaks and 8-oxo-2deoxyguanosine formation by the aldo-ketoreductase product benzo[a] pyrene-7,8-dione. J BiolChem 2009;284:29725-34

4. Wang C, Zhao Y, Zheng R, Ding X, Wei W, Zuo Z, et al. Effects of tributyltin, benzo[a]pyrene, and their mixture on antioxidant defense systems in Sebastiscus marmoratus. Ecotoxicol Environ Saf 2006;65(3):381-7

5. Alam S, Conway MJ, Chen HS, Meyers C. The cigarette smoke carcinogen benzo[a]pyrene enhances human papillomavirus synthesis. J Virol 2008;82(2):1053-8

6. Wojcik M, Burzynska-Pedziwiatr I, Wozniak LA. A review of natural and synthetic antioxidants important for health and longevity. Curr Med Chem 2010;17(28):3262-88.
7. Kunnumakkara AB, Anand P, Aggarwal BB. Curcumin inhibits proliferation, invasion, angiogenesis and metastasis of different cancers through interaction with multiple cell signaling proteins. Cancer Lett 2008;269(2):199-225.

8. Aggarwal BB. The past, present and future of multi-targeted cancer treatment "naturally": Food for thought. Cancer Lett 2008;269(2):187-8.

9. Garry S, Nesslany F, Aliouat E, Haguenoer JM, Marzin D. Hematite $(\mathrm{Fe}(2) \mathrm{O}(3))$ enhances benzo[a]pyrene genotoxicity in endotracheally treated rat, as determined by Comet Assay. Mutat Res 2003;538(1-2):19-29.

10. Das K, Samanta L, Chainy GB. A modified spectrophotometric assay of superoxide dismutase using nitrite formation by superoxide radicals. Indian J Biochem Biophys 2000;37:201-4.

11. Sinha AK. Colorimetric assay of catalase. Anal Biochem 1972;47(2):389-94.

12. Ellman GL. Tissue sulfhydryl groups. Arch Biochem Biophys 1959;82(1):70-7

13. Moron MS, Depierre JW, Mannervik B. Levels of glutathione, glutathione reductase and glutathione S-transferase activities in rat lung and liver. Biochim Biophys Acta 1979;582(1):67-78.

14. Omaye ST, Turnbull JD, Sauberlich HE. Selected methods for the determination of ascorbic acid in animal cells, tissues, and fluids. Methods Enzymol 1979;62:3-11.

15. Bishayee S, Balasubramanian AS. Lipid peroxide formation in rat brain. J Neurochem 1971;18(6):909-20.

16. Bonting SL. Sodium-potassium activated adenosine triphosphatase and cation transport. In: Bittar EE, editor. Membranes and Ion Transport. Vol. 1. London: Wiley-Interscience; 1970. p. 257-363

17. Hjertén S, Pan H. Purification and characterization of two forms of a low-affinity $\mathrm{Ca} 2$-ATPase from erythrocyte membranes. Biochim Biophys Acta 1983;728(2):281-8.

18. Ohnishi T, Suzuki T, Suzuki Y, Ozawa K. A comparative study of plasma membrane Mg2 -ATPase activities in normal, regenerating and malignant cells. Biochim Biophys Acta 1982;684(1):67-74.

19. Basu A, Imrhan V. Tomatoes versus lycopene in oxidative stress and carcinogenesis: Conclusions from clinical trials. Eur J Clin Nutr 2007;61(3):295-303

20. Franck G, Wdzieczak-Bakala J, Henrotte JG. Modulating role of glucose on magnesium transport in rat erythrocytes. J Nutr Biochem 1999;10(7):433-7

21. Srikanth S. Spectrum of cervical lesions observed in 500 cases: Carcinoma cervix the leading cause of death in females. Indian J Cancer 2016;53(1):61-2.

22. Holschneider CH, Baldwin RL, Tumber K, Aoyama C, Karlan BY. The fragile histidine triad gene: A molecular link between cigarette smoking and cervical cancer. Clin Cancer Res 2005;11(16):5756-63.

23. Kryston TB, Georgiev AB, Pissis P, Georgakilas AG. Role of oxidative stress and DNA damage in human carcinogenesis. Mutat Res 2011;711(1-2):193-201.

24. Liou GY, Storz P. Reactive oxygen species in cancer. Free Radic Res 2010;44(5):479-96.

25. Diwanay S, Chitre D, Patwardhan B. Immunoprotection by botanical drugs in cancer chemotherapy. J Ethnopharmacol 2004;90(1):49-55.

26. Huang WY, Cai YZ, Zhang Y. Natural phenolic compounds from medicinal herbs and dietary plants: Potential use for cancer prevention. Nutr Cancer 2010;62(1):1-20.

27. Pednekar PP, Vakil BV, Sane RT, Datar AG. Phytochemical profile and antioxidant activity of the essential oil from Blumea eriantha Dc. Int J Pharm Pharm Sci 2013;5(1):404-13.

28. Soobrattee MA, Bahorun T, Aruoma OI. Chemopreventive actions of polyphenolic compounds in cancer. Biofactors 2006;27(1-4):19-35.

29. Srivastava AK, Srivastava SK, Shah NC. Constituents of the rhizome essential oil of Curcuma amada Roxb. from India. J Essent Oil Res 2009;13:63-4

30. Faiz Hossain C, Al-Amin M, Rahman KM, Sarker A, Alam MM, Chowdhury $\mathrm{MH}$, et al. Analgesic principle from Curcuma amada. J Ethnopharmacol 2015;163:273-7.

31. Bai KC, Shannukanada P. Analgesic activity of aqueous extract of Curcuma amada (mango-ginger) in male albino Wister rats. J Evid Based Med Healthc 2015;2:6662.

32. Devi PH, Mazunder PB, Devi PL. Antioxidant and antimutagenic activity of Curcuma caesia Roxb, rhizome extracts. Toxicol Rep 2015;2:423-8

33. Upadhyay A, Sharma RK, Singh G, Jain AK. Evaluation of antitumor activity of Curcuma amada Roxb. Rhizome. Int J Sci Eng Res 2013;4(4):238-42. 
34. Wu YQ, Wang CG, Wang Y, Zhao Y, Chen YX, Zuo ZH. Antioxidant responses to benzo[a]pyrene, tributyltin and their mixture in the spleen of Sebasticus marmoratus. J Environ Sci (China) 2007;19(9):1129-35.

35. Chena J, Songa M, Lia Y, Zhanga Y, Tayab K, Lia CM. The effect of phytosterol protects rats against 4-nitrophenol-induced liver damage. Environ Toxicol Pharmacol 2016;41:266-71.

36. Vieira LR, Sousa A, Frasco MF, Lima I, Morgado F, Guilhermino L. Acute effects of Benzo[a]pyrene, anthracene and a fuel oil on biomarkers of the common goby Pomatoschistus microps (Teleostei, Gobiidae). Sci Total Environ 2008;395(2-3):87-100.

37. Besaratinia A, Kim SI, Bates SE, Pfeifer GP. Riboflavin activated by ultraviolet A1 irradiation induces oxidative DNA damagemediated mutations inhibited by vitamin C. Proc Natl Acad Sci U S A 2007;104(14):5953-8.

38. Maynard S, Schurman SH, Harboe C, de Souza-Pinto NC, Bohr VA. Base excision repair of oxidative DNA damage and association with cancer and aging. Carcinogenesis 2009;30(1):2-10.

39. Nijveldt RJ, van Nood E, van Hoorn DE, Boelens PG, van Norren K, van Leeuwen PA. Flavonoids: A review of probable mechanisms of action and potential applications. Am J Clin Nutr 2001;74(4):418-25.

40. Ramakrishnan G, Augustine TA, Jagan S, Vinodhkumar R, Devaki T. Effect of silymarin on N-nitrosodiethylamine induced hepatocarcinogenesis in rats. Exp Oncol 2007;29(1):39-44.

41. Vinodhkumar R, Ravikumar V, Shivashangari KS, Kamaraj S, Devaki T. Chemopreventive role of Lycopene and D-arginine in benzo(A)pyrene induced lung cancer with reference to lipid peroxidation, antioxidant system and tumour marker enzymes. Int J Cancer Res 2006;2(3):224-33.

42. Selvendiran K, Singh JP, Krishnan KB, Sakthisekaran D. Cytoprotective effect of piperine against benzo[a]pyrene induced lung cancer with reference to lipid peroxidation and antioxidant system in Swiss albino mice. Fitoterapia 2003;74(1-2):109-15.

43. Rozanida AR, Nurullzza N, Mohd Helme NH, Zanariah HA. Cosmeceutical product from species in the family Zingiberaceae. In: Mazura MP, editor. Harnessing Cures from Nature: Trends and Prospects. Kepong, Selangor, Malaysia: Forest Research Institute; 2006. p. 31-6.

44. Yingming P, Ping L, Hengshan W, Min L. Antioxidant activities of several Chinese medicinal herbs. Food Chem 2004;88:347-50.

45. Sahu R, Saxena J. Phytochemical analysis of Curcuma amada by FTIR and UV-VIS spectroscopic analysis. Int J Pharm Res Sch $2015 ; 4(1-2): 458-61$

46. Singh S, Gupta AK. Evaluation of phenolics content, flavonoids and antioxidant activity of Curcuma amada (Mango Ginger) and Zingiber officinale (Ginger). Research and Reviews. J Chem 2013;2(1):32-5.

47. Yu Z, Wang R, Xu L, Xie S, Dong J, Jing Y. B-Elemene piperazine derivatives induce apoptosis in human leukemia cells through down regulation of c-FLIP and generation of ROS. PLoS One 2011;6(1):e15843.

48. Policegoudra RS, Aradhya SM, Singh L. Mango ginger (Curcuma amada Roxb.) - a promising spice for phytochemicals and biological activities. J Biosci 2011;36(4):739-48.

49. Phongpradist R, Chaiyana W, Anuchapreeda A. Curcumin-loaded multi-valent ligands conjugated nanoparticles for anti-inflammatory activity. Int J Pharm Pharm Sci 2015;7(4):203-8.

50. Liu RH. Potential synergy of phytochemicals in cancer prevention: Mechanism of action. J Nutr 2004;134(12 Suppl):3479S-85S.

51. Vishnupriya M, Nishaa S, Sasikumar JM, Gopalakrishnan VK. Antioxidant activity and hydroxyl radical induced DNA damage protection effect of aqueous extract of Curcuma amada Roxb. Res J Pharm Biol Chem Sci 2012;3(4):89-96.

52. Sivaprabha J. Radical scavenging activity of leaves and rhizomes of Curcuma amada. Int J Pharm Res Dev 2011;3:167-74.

53. Policegoudra RS, Abiraj K, Channe Gowda D, Aradhya SM. Isolation and characterization of antioxidant and antibacterial compound from mango ginger (Curcuma amada Roxb.) rhizome. J Chromatogr B Analyt Technol Biomed Life Sci 2007;852(1-2):40-8.

54. Sahu RK, Nahak G. Evaluation of antioxidant activity in ethanolic extracts of five Curcuma species. Int Res J Pharm 2011;2(12):243-8.

55. Siegel EM, Salemi JL, Villa LL, Ferenczy A, Franco EL, Giuliano AR. Dietary consumption of antioxidant nutrients and risk of incident cervical intraepithelial neoplasia. Gynecol Oncol 2010;118:289-94.

56. Nair J, Srivatanakul P, Haas C, Jedpiyawongse A, Khuhaprema T, Seitz HK, et al. High urinary excretion of lipid peroxidation-derived
DNA damage in patients with cancer-prone liver diseases. Mutat Res 2010;683(1-2):23-8

57. Kim HS, Kwack SJ, Lee BM. Lipid peroxidation, antioxidant enzymes, and benzo[a]pyrene-quinones in the blood of rats treated with benzo[a] pyrene. Chem Biol Interact 2000;127(2):139-50.

58. Pan LQ, Ren J, Liu J. Responses of antioxidant systems and LPO level to benzo(a)pyrene and benzo(k)fluoranthene in the haemolymph of the scallop Chlamys ferrari. Environ Pollut 2006;141(3):443-51.

59. Amresh G, Rao CV, Singh PN. Antioxidant activity of Cissampelos pareira on benzo(a)pyrene-induced mucosal injury in mice. Nutr Res 2007;27:625-32.

60. Policegoudra RS, Rehna K, Rao LJ, Aradhya SM. Antimicrobial, antioxidant, cytotoxicity and platelet aggregation inhibitory activity of a novel molecule isolated and characterized from mango ginger (Curcuma amada Roxb.) rhizome. J Biosci 2010;35:231-40.

61. Tarwadi K, Agte V. Antioxidant and micronutrient quality of fruit and root vegetables from the Indian subcontinent and their comparative performance with green leafy vegetables and fruits. J Sci Food Agric 2005;85:1469-76.

62. Vishnukumar S, Rajadurai M, Stephan R, Chandra S. Effect of morin on glycoproteins and membrane bound enzymes in streptozotocininduced diabetic rats. J Acad Ind Res 2012;1:5-10.

63. Yatime L, Buch-Pedersen MJ, Musgaard M, Morth JP, Winther AM, Pedersen BP. P-type ATPases as drug targets: Tools for medicine and science. Biochem Biophys Acta 2009;1787:207-20.

64. McNulty HP, Byun J, Lockwood SF, Jacob RF, Mason RP. Differential effects of carotenoids on lipid peroxidation due to membrane interactions: X-ray diffraction analysis. Biochim Biophys Acta 2007;1768(1):167-74

65. Park JS, Chyun JH, Kim YK, Line LL, Chew BP. Astaxanthin decreased oxidative stress and inflammation and enhanced immune response in humans. Nutr Metab 2010;7:18.

66. Kolanjiappan K, Manoharan S, Kayalvizhi M. Measurement of erythrocyte lipids, lipid peroxidation, antioxidants and osmotic fragility in cervical cancer patients. Clin Chim Acta 2002;326(1-2):143-9.

67. Bhagavathy S, Sumathi P. Stabilization of membrane bound ATPases and lipid peroxidation by carotenoids from Chlorococcum humicola in Benzo(a)pyrene induced toxicity. Asian Pac J Trop Biomed 2012;2:380-4

68. Ithayarasi AP, Devi CS. Effect of alpha-tocopherol on lipid peroxidation in isoproterenol induced myocardial infarction in rats. Indian J Physiol Pharmacol 1997;41(4):369-76.

69. Denissenko MF, Pao A, Tang M, Pfeifer GP. Preferential formation of benzo[a]pyrene adducts at lung cancer mutational hotspots in P53. Science 1996;274(5286):430-2.

70. Sajid KM, Chaouachi K, Mahmood R. Hookah smoking and cancer: Carcinoembryonic antigen (CEA) levels in exclusive/ever hookah smokers. Harm Reduct J 2008;5:19.

71. Ueda Y, Enomoto T, Kimura T, Miyatake T, Yoshino K, Fujita M, et al. Serum biomarkers for early detection of gynecologic cancers. Cancers (Basel) 2010;2(2):1312-27.

72. Huang MT, Ma W, Lu YP, Chang RL, Fisher C, Manchand PS, et al. Effects of curcumin, demethoxycurcumin, bisdemethoxycurcumin and tetrahydrocurcumin on 12-O-tetradecanoylphorbol-13-acetate-induced tumor promotion. Carcinogenesis 1995;16(10):2493-7.

73. Gadducci A, Cosio S, Carpi A, Nicolini A, Genazzani AR. Serum tumor markers in the management of ovarian, endometrial and cervical cancer. Biomed Pharmacother 2004;58(1):24-38.

74. Patlolla JM, Rao CV. Triterpenoids for cancer prevention and treatment: Current status and future prospects. Curr Pharm Biotechnol 2012;13:147-55

75. Grimm C, Hofstetter G, Aust S, Mutz-Dehbalaie I, Bruch M, Heinze $\mathrm{G}$, et al. Association of gamma-glutamyltransferase with severity of disease at diagnosis and prognosis of ovarian cancer. $\mathrm{Br} \mathrm{J}$ Cancer 2013;109:610-4

76. Fentiman IS. Gamma-glutamyl transferase: Risk and prognosis of cancer. Br J Cancer 2012;106:1467-8.

77. Kim KI, Kim JW, Hong BS, Shin DH, Cho HY, Kim HK, et al. Antitumor, genotoxicity and anticlastogenic activities of polysaccharide from Curcuma zedoaria. Mol Cells 2000;10:392-8.

78. Yee H, Yie TA, Goldberg J, Wong KM, Rom WN. Immunohistochemical study of fibrosis and adenocarcinoma in dominant-negative p53 transgenic mice exposed to chrysotile asbestos and benzo(a)pyrene. J Environ Pathol Toxicol Oncol 2008;27:267-76. 